\title{
Quincy Wright: a personal memoir
}

\author{
ROBERT C. ANGELL \\ Department of Sociology (retired), University of Michigan
}

My first meeting with Quincy Wright was in March 1947. The occasion was the Twentythird Institute sponsored by the Norman Wait Harris Memorial Foundation of the University of Chicago, of which Quincy was director. The ambiance was the old Hotel Moraine in Highland Park, with its delightful grounds running down to Lake Michigan. More than forty scholars were gathered there to discuss "the world community," among them the then famous-Ruth Benedict, Harold Lasswell, Margaret Mead, Charles Merriam, Talcott Parsons, Karl Polanyi, George Stoddard, W. Lloyd Warner, Louis Wirth-and the soon to become famous-Kenneth Boulding, Jerome Bruner, Rensis Likert, Jacob Marschak, Hans Morgenthau, David Riesman, and Adlai Stevenson.

Quincy Wright was in charge of the Institute. He had procured the writing of the papers and had supervised the arrangements, and proceeded to launch the discussion and keep it on the rails for five sessions. His comments were penetrating, sometimes pungent, but always fair. He was a benign but effective shepherd. Because he had to keep a watchful eye on his flock, my moments with him were brief. My impression of him as a person was nevertheless clearly etched, and, however amplified it was by later acquaintance, it was never contradicted. I shall try to convey that impression as freshly as if 1947 were yesterday.

Quincy Wright was short and stocky, with dark hair parted near the middle, a twinkle in his eye, and a quick smile. On meeting me, a stranger, he radiated warmth and good humor. He was cordiality itself. But he was serious too. He felt responsible for the work of the Institute and was concerned to help me play my role successfully.

I well remember how the participants gathered at the bar after the session the first evening and sat around getting acquainted and swapping an occasional story. I was somewhat surprised to find that Quincy was not only a very learned man but a fluent and witty conversationalist as well. The great international lawyer was not in the least austere. Though no back-slapper, he could be one of the boys. In a small man one looks for Napoleonic traces, but there were none -just a quiet confidence that made me think of him as perky.

Although I was in another meeting the same fall with Quincy in Philadelphia, it was more than two years later that I came to know him really well. This time the locale was Paris, where I was on the staff of the Social Sciences Department of UNESCO, having taken a year's leave from the University of Michigan. Walter Laves, Quincy's former student and then Deputy Director-General of UNESCO, had suggested to his chief, Jaime Torres Bodet, that Quincy be brought over for a few weeks as consultant on the scope and methods of UNESCO. After a year in office, the Director-General was feeling the need for a thorough critique of the organization's activities and potentialities.

Quincy worked prodigiously and in a short 
period turned out a series of memoranda, one of them on the role of the Social Sciences Department. Members of our staff, including Walter Sharp of Yale, had several talks with Quincy about what we were doing and what we might do. But more revealing of the man were the informal contacts that five or six Americans on the UNESCO staff had with Quincy. Since my family had not yet come to Paris, I was more than once his companion at lunch or dinner. It was in Paris, then, that I became a fast friend and great admirer of Quincy Wright.

If reading $A$ Study of War had not already done so, the contact at UNESCO would have convinced me of the depth of Quincy's commitment to the cause of world peace. He had come a long way to do a great deal of hard work because he believed in what UNESCO was trying to accomplish. Listening to him read sections of the memoranda he was drafting, I found my earlier impression of his intelligence and breadth of grasp confirmed. In addition I realized how industrious he was and how resourceful in dealing with unfamiliar issues. Drawing as he did on a rich fund of knowledge and experience, he naturally had some confidence in the conclusions he was reaching; but when any of us raised questions, he was willing to hear and weigh our criticisms. He could be very objective in discussing his own conclusions. As a footnote, it is characteristic of the man that his memorandum on the reorientation of UNESCO's program urged more concentration on the use of education, science, and culture as means to peace and security rather than as ends in themselves.

Our informal contacts outside of working hours served to confirm my earlier impression of Quincy's affability. Since there was time to talk of many things, I came to appreciate not only his personality but his character. Essentially, he was deeply humane. He had a vision of the good life for all mankind and everything he did or said was consonant with that vision. This has been demonstrated in his life- long effort to further international law, but it showed itself also in little, intimate things. I remember vividly a Sunday when he and I had dinner at the little Versailles home of Bill and Sonia Hodson. No grandfather could have been more charming and playful than he with the two small children. The beauty of that day made the tragedy of Bill's death a year or so later (as he helped others get out of an illfated airplane down in the River Shannon) all the more poignant.

Quincy's path and mine scarcely crossed at all in the fifties. But what he stood for as a scholar and a man remained fresh in my mind. When a small group of us were planning the first issue of the Journal of Conflict Resolution Kenneth Boulding and I thought the most appropriate person in the world to write the lead article would be Quincy Wright. And thus his contribution, "The Value for Conflict Resolution of a General Discipline of International Relations," started this journal on its way. He contributed to its pages four more times before his death.

I had met Louise Wright at the Harris Foundation Institute but had had no opportunity to see the two of them as a couple until my wife Esther and I stopped off in Charlottesville one spring, whither the Wrights had removed after retirement from the University of Chicago. Louise was delayed that evening en route from New York and Quincy entertained us as we awaited her arrival. Though it would have been natural for him to lead the conversation into shop talk with me after so long an interval, he showed himself the gentleman that he was by being charming to Esther, whom he had never met before. Louise arrived full of apologies and quickly contrived a delicious dinner, after which the four of us spent a quiet evening of pleasant conversation. The Angells came to appreciate that night how deep was the community of spirit between Louise and Quincy and how warm their affection.

Following this evening in Charlottesville I saw Quincy only once-at the International 
Arms Control Symposium in 1962 -- until we had the good news that the Wrights were coming to Ann Arbor for the winter semester, January to April, 1968. Quincy was to conduct seminars in the Law School and the Political Science Department. These four months gave us the opportunity to know the Wrights better than ever before.

Quincy, now 77 instead of the 56 he had been in 1947, still looked much the same. His hair had turned gray and his face was more lined, but he was still spry, still able to shovel snow from his doorstep, still the genial host and good companion. Though he was the same admirable person, I discovered, however, that there were facets of his character that I had not fully appreciated before. This was because I had never been associated with him while he was in the midst of teaching. As he talked about the students in his seminars and about younger colleagues in the Law School, the Political Science Department, and the Center for Research of Conflict Resolution, I made three new discoveries about him.

First, Quincy was almost unbelievably modest. Despite his great contributions to international law and the study of international relations, he was not one to dwell on them. He was quick to praise the ideas and achievements of others and generous in acknowledging his indebtedness to them. A person who did not know of his eminence would never have learned of it from him.

Second, Quincy kept his pioneering spirit to the end. He showed great interest in what was going on at Michigan; he was eager to pick up leads that might take his own research in new directions. Always one to range broadly across the fields of social science, he retained the spirit of adventure that had served him so well throughout his career.

Finally, Quincy was young at heart. He liked to meet young people, to talk about their work and their plans, to give them the benefit of his counsel. He was generous of his time and knowledge. No wonder that his students have drawn lasting inspiration from their association with him.

And so a great man departs, leaving us all the richer for having passed this way. 